\title{
PERAN GURU BIMBEL DALAM PENDIDIKAN KARAKTER ANAK PADA MASA PANDEMI COVID-19 DI DESA KAMPUNGBARU, TANJUNGANOM, NGANJUK
}

\author{
Sulih Lucky Virgianti \\ Pendidikan Agama Islam (PAI), Institut Agama Islam Negeri (IAIN) Kediri \\ sulihlucky010901@gmail.com \\ Agus Miftakus Surur \\ Institut Agama Islam Negeri (IAIN) Kediri \\ surur.math@gmail.com
}

\begin{abstract}
Abstrak:
Penelitian ini mengusung judul tentang "Peran Guru dalam Pendidikan Karakter Anak pada Masa Pandemi Covid-19 di Desa Kampungbaru, Tanjunganom, Nganjuk". Penelitian ini memiliki tujuan yakni dapat mengembangkan serta menanamkan pendidikan karakter kepada anak yakng saat ini semakin hari semakin memudar karena terkikis oleh peradapan zaman yang samakin maju. Penanaman pendidikan karakter kepada anak diharapkan untuk dapat mengembangkan nilai-nilai yang positif dan dapat membentuk kepribadian anak menjadi lebih baik. Penelitian ini menggunakan pendeketan kualitatif dengan metode penelitian Asset Based Community Development (ABCD). Dalam pelaksanaan penelitian ini ditemukan bahwasanya perilaku atau tindakan yang dilakukan secara terus menerus dan dilakukan secara berulang-ulang akan menghasilkan hasil yang baik. Pendidikan karakter yang dilakukan oleh guru bimbel "Smart House"memberikan hasil yang baik untuk membentuk kepribadian anak secara permanen.
\end{abstract}

Kata kunci: Peran Guru Bimbel, Pendidikan Karakter, Masa Pandemi Covid-19

\begin{abstract}
:
This research carries the title about "The Role of Teachers in Children's Character Education During the Pandemic Covid-19 in the Village Kampungbaru, Tanjunganom, Nagnjuk.". This study aims to be able to develop and instill character education in children who are currently fading due to being eroded by an increasingly advanced civilization. Instilling character education in children is expected to be able to develop positive values and can shape the child's personality for the better. This study uses a qualitative approach with research methods Asset Based Community Development $(A B C D)$. In the implementation of this research, it was found that behavior or actions that are carried out continuously and are carried out repeatedly will produce good results. Character education is carried out by tutors "Smart House" give good results to shape the child's personality permanently.
\end{abstract}

Keywords: The Role of Tutoring Teacher, Character Education, Covid-19 Pandemic Period

\section{PENDAHULUAN}

Dalam kehidupan manusia, kata pendidikan tidaklah terlepas dalam segala kegiatan. Keberadaan pendidikan dan pengajaran sangatlah berperan penting bagi manusia, yakni memiliki peranan sentral dalam membina dan menunjukkan serta memotivasi individu dan masyrakat agar 


\section{Peran Guru Bimbel Dalam Pendidikan Karakter Anak}

dapat meningktkan kualitas yang ada pada dirinya dalam segala aspek bidang kehidupan untuk dapat meraih kemajuan dan selain itu untuk dapat menunjang kehidupan yang akan datang Dalam kehidupan manusia, kata pendidikan tidaklah terlepas dalam segala kegiatan. Keberadaan pendidikan dan pengajaran sangatlah berperan penting bagi manusia, yakni memiliki peranan sentral dalam membina dan menunjukkan serta memotivasi individu dan masyarakat agar dapat meningktkan kualitas yang ada pada dirinya dalam segala aspek bidang kehidupan untuk dapat meraih kemajuan dan selain itu untuk dapat menunjang kehidupan yang akan datang Dalam kehidupan manusia, kata pendidikan tidaklah terlepas dalam segala kegiatan. Keberadaan pendidikan dan pengajaran sangatlah berperan penting bagi manusia, yakni memiliki peranan sentral dalam membina dan menunjukkan serta memotivasi individu dan masyrakat agar dapat meningktkan kualitas yang ada pada dirinya dalam segala aspek bidang kehidupan untuk dapat meraih kemajuan dan selain itu untuk dapat menunjang kehidupan yang akan datang. ${ }^{1}$

Pendidikan merupakan suatu pengembangan pada pembudayaan manusia yang muda agar hidup dikutip dari Undang-Undang Sistem Pendidikan Nasional No. 20 Tahun 2003, mengenai pendidikan. Menurutnya Pendidikan merupakan bentuk dari suatu usaha yang secara sadar dan tersusun agar dapat mewujudkan kondisi belajar didalam proses pembelajaran sehingga peserta didik secara aktif dapat memperkaya kemampuan yang dimiliki dirinya untuk mempunyai keahlian dalam bidang relegius, kontrol diri, identitas diri, kepandaian, perilaku yang baik, serta kekreatifitasan yang di perlukan individu dan masyarakat sekitarnya. ${ }^{2}$

Dalam proses pendidikan sendiri memiliki tujuan yang ingin terwujud yakni adanya kedewasaan pada jasmani dan rohaninya. Yang dimaksud dengan kedewasaan pada proses pendidikan ini adalah jika seseorang tersebut sudah besar badannya secara fisik, maka dia sudah besar atas kemampuaannya serta dia sudah bisa melakukan tugas di dalam hidupnya yang selaras dengan tuntutan atau norma yang telah berlaku di masyarakat dan dapat mempertanggung jawabkan atas apa yang telah di perbuat atau di lakukannya sendiri. ${ }^{3}$

Selain belajar disekolah peserta didik dapat belajar diluar rumah, misalnya adalah bimbel. Bimbel atau bimbingan belajar mempunyai fungsi sebagai membantu serta menunjang usaha dari peserta didik untuk kearah maju dalam bidang belajar. Bimbel diharapkan dapat membantu serta mengatasi kesulitan belajar yang sedang dialami oleh peserta didik. Bimbel pasti memiliki manfaat positif bagi tumbuh kembang peserta didik. Dalam bimbel tidak hanya membantu persoalan siswa dalam hal belajar saja melainkan juga bisa yang lainnya. ${ }^{4}$

\footnotetext{
${ }^{1}$ Halid Hanafi, La Adu, and Zainuddin, Ilmu Pendidikan Islam (1 Ed.) (Deepublish, 2018).

${ }^{2}$ A. N. Neoloka and G. A. A, Landasan Pendidikan (1 Ed.) (Kencana, 2017).

${ }^{3}$ S. Zen and Z, Dasar-Dasar Ilmu Pendidikan (1 Ed.) (Kencana, 2017).

${ }^{4}$ Oktaviani Dwi Saputri and Rahmawati, "Peran Guru Dalam Memberikan Pelajaran Tambahan (LES) Bagi Peserta Dididk Di Luar Jam Pelajaran Sekolah Sebagai Wujud Implementasi Pengapdian Kepada Masyarakat.," in Seminar Nasional Pendidikan Program Pascasarjana Universitas PGRI Palembang, 2019.
} 
Dalam bimbel anak tidak hanya diajar mengenai materi pembelajara saja melainkan juga mengenai pendidikan karakter. Pendidikan karakter berkaitan erat dengan moral serta kepribadian, karakter sendiri harus diberlakukan dalam hal kebiasaan serta keteladanan. Guru biasanya memberikan motivasi, tata tertib dan lain sebagainya agar karakter anak menjadi berkembang sesuai dengan aturan. ${ }^{5}$

Masa pandemi, membuat pemerintah menerapkan kebijakan mengenai pendidikan yakni pembelajaran daring (dalam jaringan) yang telah diberlakukan diseluruh Indonesia. Masa pandemi membuat anak belajar dirumah. dalam pembelajaran daring guru dituntut untuk dapat kreativitas serta terampil dalam mengolah pembelajaran sehingga anak tidak merasa jenuh dan bosan dalam hal belajar. ${ }^{6}$ Orang tua memilih anaknya masuk bimbel dibandingkan dengan belajar sendiri karena dengan bimbel anak akan diajari dalam berbagai hal, seperti halnya belajar di sekolah. Sekarang ini karakter anak semakin menurun karena mereka kebanyakan bermain serta melakukan aktivitas yang kurang bermanfaat. ${ }^{7}$ Oleh karena itulah dalam hal ini guru bimbel seringkali memberikan pendidikan karakter kepada peserta didik dalam hal sengaja atau tidak sengaja.

Karakter yang harus ditumbuhkan pada anak yakni mengenai tata krama dan sopan santun terhadap sesama serta orang tua, serta mengajarkan berperilaku yang baik terhadap anak. ${ }^{8}$ Tujuan dari ditumbuhkannya pendidikan karakter anak sejak dini agar anak menjadi terbiasa mengucap dan berperilaku sesuai dengan tata krama, sopan santun dan juga sesuai dengan ketentuan agama. Pendidikan karakter harus diajarkan anak sejak dini untuk dapat menjadi penerus generasi bangsa yang berkarakter yang berbudi luhur dan dapat menjunjung nama baik keluarga, masyarakat, daerah, bangsa dan negara. Pendidikan karakter diperoleh tidak hanya di dalam keluarga saja, namun bisa di dalam sekolah dan diluar sekolah (bimbel, masyarakat, teman sebaya dan lain sebagainya.

\section{KAJIAN TEORI}

\section{Peran Guru Bimbel}

Bimbingan belajar merupakan suatu tahapan dalam pembelajaran agar dapat memberikan pengaruh terhadap anak atau peserta didik untuk mendapatkan hasil yang baik sehinggaa bisa di terapkan dalam kehidupan sehari-hari. Peran guru bimbel sama halnya dengan peran guru lainnya adalah sebgai model, sebagai perencana, sebagai peramal, sebagai pemimpin, dan sebagai penunjuk

\footnotetext{
${ }^{5}$ Abdullah S. Ridwan and M. Kadri, Pendidikan Karakter: Pengembangan Karakter Anak Yang Islami (Cet1) (Bumi Aksara, 2016).

6 Aminullah, "Proses Pembelajaran Selama Masa Pandami Covid 19 (Studi KasusPelaksanaan PLP Dasar," Muspul Journal of Community Empowerment 3, no. 1 (2021).

${ }^{7}$ Agus Miftakus Surur, “Standart Kinerja Pengajaran Dosen Pendidikan Matematik," Factor M 2, no. 1 (2019).

${ }^{8}$ S Hamid Hasan, "Pendidikan Sejarah Untuk Memperkuat Pendidikan Karakter," Paramita: Historical Studies Journal 22, no. 1 (2012).
} 


\section{Peran Guru Bimbel Dalam Pendidikan Karakter Anak}

jalan atau bimbingan ke arah pusat belajar. Selain itu peran guru ialah sebagai pengorganisasi lingkungan belajar dan sekaligus sebagai fasilitator belajar. ${ }^{9}$

Menurut Askhabul K, yang mengutip penjelasan dari Gery F, dan Wiliam H., menegaskan bahwasanya peran guru dalam gambaran masa depan adalah:

a. Memberikan stimulasi kepada siswa dengan menyediakan tugas-tugas pembelajaran yang kaya (rich learning tasks) dan terancang dengan baik untuk dapat meningkatkan perkembangan intelektual. Emosional, spiritual, dan sosial.

b. Berinteraksi dengan peserta didik agar dapat mendorong keberanian, mengilhami, menantang, berdiskusi, berbagi, menjelaskan, menegaskan, merefleksi, menilai, dan merayakan perkembangan, pertumbuhan dan keberhasilan.

c. Menunjukkan manfaat yang didapatkan dari hasil apa yang dia pelajari suatu pokok pembahasan.

d. Berperan sebagai seorang yang membantu, orang yang mengarahkan dan memberikan pengarahan, orang yang memberikan jiwa dan mengilhami peserta didik dengan cara membangkitkan rasa ingin tahunya, rasa antusias, rasa bergairah dari seorang pelajar yang berani untuk dapat mengambil resiko (risk taking learning), oleh karena itu guru berperan sebagai pemberi informasi (informer), fasilitator dan seorang artis. ${ }^{10}$

Peran guru menggambarkan pola tingkah laku yang diharapkan dalam berbagai interaksi, baik hal tersebut dengan peserta didik, sesama guru, ataupun dengan sesama staf dan lainnya. dari berbagai interaksi pola belajar mengajar, dapat dilihat bahwasanya guru memiliki peran sentral didalamnya dan dalam peranannya. Peran seorang guru sangatlah signifikan bagi setiap keberhasilan proses pembelajaran. Guru berperan aktif, imajinatif, hipotetik, sinetik, dan mampu menjadi idola dari setiap peserta didik. ${ }^{11}$

\section{Pendidikan Karakter}

Pendidikan karakter merupakan suatu pendidikan yang dapat menanmpakan sebuah nilai karakte keada seluruh manusia yang terdiri dari komponen pengetahuan, serta mempunyai kesadaran atau potensi agar dapat melaksanakan nilai-nilai baik terhadap Tuhan Yang Maha Esa, diri sendiri, serta lingkungan yang ada disekitar. ${ }^{12}$

\footnotetext{
${ }^{9}$ Muh. Zein, "Peran Guru Dalam Pengembangan Pelajaran.," Jurnal Inspirasi Pendidikan 5, no. 2 (2016).

${ }^{10}$ A Kirom, "Peran Guru Dan Peserta Didik Dalam Proses Pembelajaran Berbasis Multikultural," Al-MuKirom, Arabbi: Jurnal Pendidikan Agama Islam 3, no. 1 (2017).

${ }^{11}$ Imam Suwardi Wibowo and Ririn Farnisa, "Hubungan Peran Guru Dalam Proses Pembelajaran Terhadap Prestasi Belajar Siswa," Jurnal Genatala Pendidikan Dasar 3, no. 2 (2018).

${ }^{12}$ Nella Agustin, Peran Guru Membentuk Karakter Siswa (Antologi Esai Mahasiswa Pendidikan Guru Sekolah Dasar) (UAD Press, 2021).
} 
Menurut Nurul A.S., menjelaskan bahwa pembentukan karakter bagi peserta didik ada beberapa hal sederhana yang isa ilakukan oleh seoranhg guru dabn peserta didik dalam kegiatan pembelajaran adalah:

a. Jadikan diri sebagai contoh. Guru dipandang sebagai orang tua yang lebih dewasa, sehingga peserta didik menilai wahwa guru merupakan suatu contoh yang harus ditiru dalam bertindak serta berperilaku.

b. Jadilah guru yang tidak hanya mementingkan nilai akademis, namun juga mengapresiasi usaha peserta didik. Jika hal tersebut sering kali dilakukan maka akan membangun suatu karakter yang terus ingin belajar dan memperbaiki diri untuk menjadi lebih baik lagi.

c. Lebih dari sekedar mengajar, namun juga menanamkan nilai moral pada pelajaran. Dalam setiap pengajaran usahakan kaitkan nilai moral yang ada dilingkungan sekitar agar anak lebih memahami dan dapat merealisasikannya.

d. Jujur pada diri sendidi dan terbuka pada kesalahan. Guru juga seorang manusia yang pasti mempunyai kesalahan, misalnya: terlambat mengajar. Guru harus menyadari kesalahannya dan meminta maaf kepada peserta didik serta mengejarkan sopan santun dan beradap.

e. Memberi kesempatan pada murid untuk belajar memimpin. Memanamkan kemandirian, keberanian serta tanggung jawab dan segala sesuatu.

f. Berbagi pengalaman sebagai cerita inspiratif. Tidak ada salahnya untuk menceritakan pengelaman pribadi yang dimiliki agar dapat menginspirasi peserta didik dalam belajar serta bertingkah laku. ${ }^{13}$

Menurut Ridwan A.S., dan Muhammad K., dalam bukunya yang berjudul "Pendidikan Karakter: Mengembangkan Karakter Anak yang Islami”, menjelaskan bahwasanya pengembangan karakter terhadap anak biasanya memerlukan pembiasaan serta keteladanan. Anak dibisakan dalam berbuat serta bertindak yang baik dan malu atas tindakan yang jahat atau kurang baik, berperilaku jujur dan merasa malu dalam hal berbohong bahkan berbuat curang, selalu brsikap rajin dan malu untuk malas-malasan, dan lain sebagainya. Perubahan tersebut harus dilatih secara berkelanjutan agar dapat mencapai tujuan yang diinginkan. Pendidikan karakter anak sangatlah erat dengan dengan moral dan kepribadian. Upaya pendidik terkait dengan pemberian karakter kepada anak yakni dengan cara memotivasinya. ${ }^{14}$

\footnotetext{
${ }^{13}$ Nurul Amelia Sofianti, "Peran Bimbingan Belajar Pendidikan Agama Islam Dalam Pembentukan Karakter Peserta Didik Kelas II Di SDIT Assalam Pasirandu Curug Tangerang," JM2PI: Jurnal Mediakarya Mahasiswa Pendidi-Kan Islam 1, no. 1 (2020).

${ }^{14}$ Ridwan and Kadri, Pendidikan Karakter: Pengembangan Karakter Anak Yang Islami (Cet-1).
} 


\section{Peran Guru Bimbel Dalam Pendidikan Karakter Anak}

\section{Masa Pandemi Covid-19}

Covid-19 merupaka suatu abah penyakit yang menular serta mematikan karena disebabkan berbagai virus variasi baru yakni Sars-coV-2 yang pertama kali dijumpai du Wuhan, Tiongok, pada tanggal 31 Desember 2019. Sekarang ini Negara Indonesia sedang dilanda oleh virus ini yang menyebabkan angka kematian manusia semakin hari semakin meningkat. Dengan timbulnya virus ini yang membahayakan semua orang, sehingga membuat pemerintah memberikan kebijakan untuk membatasi aktivitas di luar rumah dan selalu mematuhi protokol kesehatan yaang telah diberlakukan. Hal tersebut dilakukan untuk dapat mengurangi angka kematian manusia untuk setiap harinya, serta meredakan virus corona ini.

Masa pandemi covid-19 telah melanda seluruh penjuru dunia termasuk negara Indonesia. Negera Indonesia memiliki dampak cukup besar dengan adanya virus ini baik dalam sektor bidang pendidikan, perekonomian, industri, dan lain sebagainya. Pemerintah Indonesia membuat kebijakan Pembatasan Sosial Berskala Besar (PSBB), hal ini dilakukan untuk dapat mengurangi laju penyebaran virus corona, selain itu ada pula pemberlakuan untuk dunia pendidikan dari segala dan berbagai jenjang pendidikan yakni Pembelajaran Jarak Jauh (PJJ).

Kebijakan dalam dunia pendidikan ini dilakukan secara online dengan memanfaatkan media teknologi serta berbagai media pembelajaran. Pembelajaran dilakukan secara online ini sering kali disebut dengan Daring (dalam jaringan) karena kegiatan pembelajaran dapat dilakukan di rumah atau dimana saja dengan menggunakan alat bantu teknologi. ${ }^{15}$

\section{METODE PENELITIAN}

\section{Pendekatan penelitian}

Pendekatan yang digunakan dalam penelitian ini adalah pendekatan penelitian kualitatif. Penelitian kualitatif merupakan penelitian yang menghasilkan temuan-temuan yang tidak dapat dicapai dengan prosedur statistik atau dengan cara-cara kuantifikasi. ${ }^{16}$ Selain itu dalam pendampingan masyarakat ini menggunakan metode Asset Based Community Development (ABCD), dalam hal ini yakni lebih menitik beratkan pada aset dan juga potensi yang dimiliki serta selanjutnya dipakai sebagai bahan untuk memberdayakannya. Pendekataan ABCD lebih mengarah pada cara berpikir positif serta mengajak seseorang untuk memiliki sikap positif pula dalam kehidupan seharihari. ${ }^{17}$

${ }^{15}$ Irinna Aulia Nafrin and Hudaidah, "Perkembangan Pendidikan Indonesia Di Masa Panemi Covid-19," Edukatif: Jurnal Ilmu Pendidikan 3, no. 2 (2021).

${ }^{16}$ M. D. G. Almansyur and F., Metode Penelitian Kualitatif (Ar-Ruzz Media, 2012).

${ }^{17}$ Nurul Mahmudah and Supiah, "Pemberdayaan Pada Anak-Anak Gang Dolly Di SMA Artaktika Surabaya Dengan Metode Asset Based Community Development," Madani 1, no. 1 (2018). 


\section{Jenis Penelitian}

Jenis penelitian yang dilakukan adalah jenis penelitian studi kasus. Penelitian studi kasus merupakan suatu proses pengumpulan data dan informasi secara mendalam, mendetail, intensif, holistik dan sistematis tentang orang, kejadian, social setting (lattar sosial), atau kelompok yang menggunakan metode dan tehnik, serta banyak sumber informasi untuk memahami secara efektif bagaimana orang, kejadian, latar alami itu beroprasi atau berfungsi sesuai dengan konteksnya. ${ }^{18}$

\section{Sumber data}

a. Data internal dan ekternal. Data internal adalah data yang berasal dari dalam organisasi tersebut, sedangkan data eksternal yakni berasal dari luar organisasi.

b. Data primer dan sekunder. Data primer diperoleh melalui survei lapangan dengan menggunakan metode pengumpulan data original. Sedangkan data sekunder ialah data yang dikumpulkan oleh lembaga pengumpul dan dipublis kepada masyarakat pengguna data. ${ }^{19}$

\section{PEMBAHASAN}

\section{Peran Guru Bimbel di Masa Pandemi Covid-19}

Sekarang ini virus corona masih melanda Negara Indonsia, sehingga mengakibatkan pendidikan masih dilakukan di rumah dengan menggunakan sistem pembelajaran jarak jauh (PJJ). Pembelajaran dilakukan dengan sistem online dan dapat dilakukan dimana saja, baik dirumah, di telkom, dan lain-lain. Berbagai upaya telah dilakukan oleh pemerintah agar pendidikan di Indonesia berjalan engan baik walaupun sedang terhampat karena adanya virus ini. Pembelajaran dilakukan dengan daring dengan alasan agar peserta didik aman dan terhindar dari virus corona, selain itu agar dapat mengurangi angka kematian serta terdampak dari virus corona. Selama pembelajaran dirumah banyak orang tua yang mengeluh mengenai kebijakan ini, apalagi orang yang tinggal di desa karena mereka kebingungan saat jam belajar anak sama dengan jam kerja orang tua, serta banyak orang tua yang kurang faham mengenaai pembelajan mereka dan lain-lain.

Hal tersebut juga dijelaskan oleh Imam M, bahwa persoalan umum ang sering dihadapi oleh orang tua adalah a) Jam belajar anak bersamaan de ngan jam bekerja orang tuanya, b) orang tua kurang memahami mengenai pembeajaran anak jaman sekarang, c) Jaringan internet yang sekarang ini kurang stabil sehingga menghambat belajar anak, d) Anak merasa kurang fokus belajar dirumah, dan juga terkadang anak kurang faham dengan materi apa yang sedang diajarkan oleh guru

\footnotetext{
${ }^{18}$ M Yusuf, Metode Penelitian: Kualitatif, Kuantitatif Dan Penelitian (Kencana, 2017).

19 Hermansyah et al., Modul Pengembangan Diri Melalui Layanan Bimbingan Dan Konseling SMK (Yogyakarta: Paramitha Publishing, 2009).
} 


\section{Peran Guru Bimbel Dalam Pendidikan Karakter Anak}

melalui media internet, e) Internalisasi dalam pendidikan karakter kurang terealisasi dengan baik saat pembelajaran dilakukan dengan sistem daring. ${ }^{20}$

Selama diberlakukannya PJJ dan pembelajaran dilakukan dengan cara daring membuat banyak orang tua yang bingung dengan anak belajar di rumah karena anak takut kurang memahami materi pembelajaran dan juga anak akan cenderung main hanphone. Para orang tua merasakan kesulitan dalam mengatasi anaknya dalam hal belajar sehingga memiliki alternatif untuk memasukkannya dalam bimbingan belajar di luar sekolah. Mereka ingin bahwa anaknya akan berhasil untuk mencapai tujuan serta mencapai semua keinginannya di masa depan.

Peneliti melihat dan merasakan hal tersebut, maka membuat inisiatif untuk mendirikan bimbingan belajar. Karena saat ini posisinya adalah masih adanya wabah corona sehingga harus izin terhadap pemerintahan setempat yakni Pak RT, untuk dapat mendirikan sebuah bimbingan belajar di daerahnya. Pak RT sangan antusias serta mendukung dengan adanya bimbingan belajar yang ada di daerahnya. Selanjutnya pak RT memberitahukan kepada masyarakat dengan cara dari satu orang keorang lainnya sehingga anak-anak mendaftar dan masuk dalam bimbingan belajar "Star House". Dalam bimingan belajar, tidak hanya menekankan pada pendidikan ilmu pengetahuan saja melainkan juga dengan menanamkan nilai pendidikan karakter kepada anak.

Sebenarnya peran guru bimbingan belajar dengan guru lainnya yang berda di sekolah ialah sama, yakni mengajarkan anak atau peserta didik untuk dapat menguasai materi pelajaran, membimbing anak untuk memahami materi, memotivasi anak, mendukung anak dalam kegiatan yang poitif, sebagai teman, sebagai panutan dan lain sebagainya. Peran guru dalam hal pendidikan merupakan hal yang penting yang mana guru adalah orang tua kedua setelah orang tuanya dirumah. Selain mengajarkan ilmu pengetahuan guru juga mengajarkan dan menanamkan nilai-nilai moral, budi pekerti dan agama pada anak memalalui berbagai cara, baik itu secara langsung atau tidak langsung.

Menurut Siti M. dan Muhammad A., dalam bukunya yang berjudul "Peran Guru, Orang Tua, Metode, dan Media Pembelajaran: Starategi KBM di Masa Pandemi Covid-19“, memaparkan bahwasanya peran guru secara umum dapat membentuk karakter anak ialah :

a. Sebagai Pendidik dan Pengajar. Sebagai pendidik guru perlu mempunyai standar kepribadian yang mencangkup mengenai tanggung jawab, wibawa, mandiri, dan juga disiplin.

\footnotetext{
${ }^{20}$ Imam Mawardi, "Pendampingan Belajar Di Rumah Berbasis Karakter Dengan Nilai-Nilai Religius Pada Masa Pandemik Covid-19," Jurnal Terapan Abdimas 6, no. 2 (2021).
} 
b. Sebagai Fasilitator dan juga Mediator. Dalam hal ini ada empat komponen utama dalam pembelajaran aktif yang harus dimengerti oleh guru yakn pengalaman, komunikasi, interaksi dan refleksi. ${ }^{21}$

c. Sebagai Model. Dalam proses belajar mengajar guru memiliki kapasitas dalam memberikan contoh yang baik atau suri tauladan yang baik.

d. Sebagai Pembimbing. Guru memiliki peran untuk dapat membimbing anak-anak atau peserta didik kearah yang benar, memandu serta mendampingi anak dalam melakukan suatu kebiasaan.

e. Sebagai Pelatih. Pengembangan moral memerlukan pembiasaan, latihan dan pengulangan pada bentuk perilakudan perbuatan yang positif, sehingga dapat membentuk suatu karakter.

f. Sebagai Penilai. Guru sebagai evaluasi yang dapat mengukur serta mengetahui tingkat ketercapaian dan keberhasilan program pembelajaran anak. ${ }^{22}$

\section{Pendidikan Karakter melalui Peran Guru Bimbel}

Dalam penelitian dapat terlihat bahwasanya guru bimbingan belajar memberikan pendidikan karakter kepada anak melalui berbagai tahapan, seperti halnya: a) menanamkan suatu nilai yang positif dan baik kepada anak melalui berbagai pengajaran (agama, PPKN, dan sebagainya); b) membentuk karakter anak dengan cara memotivasinya, memberikan arahan serta nasehat; c) memberikan contoh yang baik kepada anak; d) dan lain - lain.

Menurut Siti A., dalam bukunya yang berjudul "Perkembangan Peserta Didik dan Bimbingan Belajar", memaparkan bahwa pendidikan karakter dapat terbentuk dengan melalui 5 tahapan yakni:

a. Adanya suatu nilai yang diserap oleh individu dari berbagai sumber yang diperoleh seperti dari agama, idiologi da pendidikan

b. Nilai akan memberntuk pola pikir dari peserta didik dengan keseluruhan keluar berupa bentuk dalam rumusan visi

c. Visi turun kedaerah hati sehingga membentuk jiwa secara menyeluruh dan membentuk mentalitas

d. Mentalitas mengalir memasuki wilayah fisik dan menciptakan tindakan yang secara keseluruhan membentuk sikap

${ }^{21}$ Siti Maemunawati dan Muhammad Arif, Peran Guru, Orang Tua, Metode, Dan Media Pembelajaran: Starategi KBM Di Masa Pandemi Covid-19 (Penerbit 3M Media Karya Serang, 2020).

${ }^{22}$ Nancy Florida Siagian, Guru Dan Perubahan: Peran Guru Di Dunia Pendidikan Dan Pembenagunan Sumber Daya Manusia (Global Aksara Pres, n.d.). 


\section{Peran Guru Bimbel Dalam Pendidikan Karakter Anak}

e. Sikap akan lebih dominan dalam diri seseorang yang secara keseluruhan mencitrai dirinya, hal tersebut disebut karakter atau kepribadian. ${ }^{23}$

Bimbingan belajar "Smart House" yang berada di Desa Kampungbaru, Tanjunganom, Nganjuk, memperlihatkan bahwasanya tidak hanya membantu anak-anak dalam mata pelajaraan saja melainkan juga menanamkan nilai-nilai moral, agama dan kebiasaan yang baik serta positif dalam bimbingan belajar. Cara yang dilakukan untuk dapat membentuk karakter anak ialah dengan memberikan arahan, memberikan contoh dalam kehidupan sehari-hari, memberi motivasi, memberi bimbingan, memberikan suatu aturan atau tata tertib, memberikan sanksi jika melakukan perbuatan yang kurang baik, membiasakan berbuat baik dan sebagainya.

a. Memberikan arahan. Memberikan arahan kepada anak tidak semudah apa yang terlihat, yakni harus memiliki kesabaran yang ekstra. Dimana anak memiliki kepribadian sendirisendiri dan terkadang sulit untuk di atur bahkan dikasih tau. Cara yang dilakukan yakni ialah dengan sedikit-demi sedikit dekat dengan anak melalui komunikasi, dan perlahan-lahan diberikan arahan untuk dapat berubah menjadi lebih baik, serta mengaitkan pelajaran dalam suatu hal yang berhubungan dengan tingkah laku.

b. Memberikan contoh dalam kehidupan sehari-hari. Anak jaman sekarang sukanya melihat getget sehingga apa yang ada digetget baik atau buruk langsung ditirukan dan menjadi trending, dan mereka tidak mengetahui bahwa perbuatan tersebut adalah buruk contohnya: menyapa teman dengan kata "Woy, Cok, Gog, Ngap dan lain-lain", Berkata dengan teman dengan menggunakan kata yang kurang baik (Ndasmu, Raimu, Anjirr, Asem, dll), berperilaku yang kurang sopan (mendorong, memukul teman, membully) dan masih banyak lagi . Cara yang dapat dilakukan yakni dengan memberikan contoh dalam kehidupaan sehari-hari, misalnya : menyapa teman jika bertemu atau berpapasan dengan baik (Assalamu'alaikum, Hy Dewi, Tersenyum), tidak mengucapkan kalimat atau kata yang kotor, berperilaku yang baik dan selalu berteman dengan siapa saja, tidak membully temannya dan sebagainya.

c. Memberikan bimbingan dan motivasi. Anak perlu dibimbing saat anak tidak mengetahui bahwa tindakannya tersebut sebenarnya salah. Bimbingan yang dimaksudkan yakni memberikan penjelasan kepada anak bahwa tindakan yang semacam itu tidak baik dan harus di tinggalkan, serta membrikan masukan untuk bertindak lebih baik lagi. Sedangkan

${ }^{23}$ S. Aisyah, Perkembangan Peserta Didik Dan Bimbingan Belajar (Ed. 1). (Deeppublish, 2015). 
memberikan motivasi yakni agar menjadi tergerak sanubarinya untuk bertindak lebih baik kedepannya agar kelak dimasa yang akan datang menjadi orang yang dapat sukses dan hebat.

d. Memberikan suatu aturan dan tata tertib kepada anak. Aturan dibuat adalah untuk dipatuhi, maka semua anak atau peserta didik harus mematuhinya. Contoh tata tertib: masuk ruangan harus mengucapkan salam, berjabat tangan dengan guru, tidak boleh makan didalam ruangan saat belajar, tidak menggunakan kata kotor, berperilaku yang baik dan sopan, tidak membawa HP, jika tidak ada kepentigan yang mendeesak, tidak boleh keluar dari ruangan sebelum adanya izin dari guru.

e. Memberikan sanksi jika melanggar tata tertib. Sanksi yang dibuat jangan sampe memberatkan anak atau peserta didik, namun sanksi yang dibuat haruslah dengan menanamkan nilai pendidikan yakni dengan cara: menulis dan menghafal surat pendek, menyanyikan lagu-lagu nasional dan sebagainya.

Pendidikan karakter yang diberikan oleh guru bimbel "Smart House" selama pembelajaran berlangsung secara langsung dan dilakukan secara berkala dan terus menerus dilakukan akan memberikan dampak positif kepada anak-anak. Anak-anak diajarkan pendidikan karakter seperti mengenai tata krama, sopan santun, adat istiadat, dan juga agama. Hal ini dilakukan untuk dapat membuat karakter anak menjadi lebih baik lagi dan menjadi karakter yang kuat pada anak. Penanaman tata karama yang dilakukan oleh guru bimbel "Smart House" adalah :

a. Makan dan minum harus dengan duduk, tidak boleh dengan berdiri

b. Makan dan minum tidak boleh dengan tiduran

c. Makan dan minum tidak boleh sambil berbicara

d. Saat membaca dan menulis usahakan badan harus tegak, tidak boleh membukuk dan bahkan dengan tiduran

e. Membaca dan menulis ditempat yang terang dan jangan di tempat yang redup

f. Dan sebagainya.

Penanaman mengenai sopan santun yang dibiasakan oleh guru bimbel "Smart House" yaitu:

a. Menyapa teman jika bertemu di jalan dengan bahasa yang baik dan santun

b. Menyapa orang yang lebih tua dengan menganggukkan kepala dan juga tersenyum

c. Menghargai dan juga menghormati orang yang lebih tua

d. Tidak clometan atau berkata kasar di mana saja

e. Tidak melakukan perbuatan yang tidak baik 


\section{Peran Guru Bimbel Dalam Pendidikan Karakter Anak}

f. Dan lain-lain.

Sedangkan penanaman pendidikan karakter anak melalui agama yakni dengan cara :

a. Mengucapkan salam ketika hendak masuk dan keluar rumah atau bertamu, dan jika masuk ruangan

b. Menyucap kalimat tarji jika mengalami musibah, misal: terjatuh, tersandung, ada orang meninggal

c. Mengucapkan kalimaat hamdallah, jika hendak bersyukur kepada Allah, misal: mendapat nilai bagus

d. Mengucap kalimat istigfar, ketika kita akan bertindak sesuatu

e. Dan seterusnya.

\section{SIMPULAN}

Guru bimbel memiliki peran yang sama dalam pendidikan karakter seorang anak. Guru bimbel tidak hanya membantu anak atau peserta didik dalam mata pelajaran saja melainkan juga ikut serta membentuk karakter anak yang memiliki karakter yang baik dan positif. Karakter anak haruslah dibentuk dengan cara menanamkannya sejak dina dan dilakukan secara terus menerus dan berulang-ulang agar dapat menghasilkan hasil yang baik dan bahkan maksimal. Pendidikan karakter yang ditanamkan kepada anak ialah mengenai tata krama, sopan santu, dan juga agama, hal ini dilakukan karena karakter anak semakin hari semakin menurun.

Diharapkan dari berbagai golongan, baik itu golongan anak-anak, anak mudan dan orang dewasa untuk senantiasa menanamkan pendidikan karakter disekitarnya agar pendidikan karakter tidak terkikis oleh perkembangan zaman. Penanaman pendidikan karakter yanga baik dan positif akan membuat karalter seseorang melekat dan membentuk kepribadian sesoang menjadi lebih baik.

\section{DAFTAR PUSTAKA}

Aisyah, S. Perkembangan Peserta Didik Dan Bimbingan Belajar (Ed. 1). Deeppublish, 2015.

Almansyur, M. D. G., and F. Metode Penelitian Kualitatif. Ar-Ruzz Media, 2012.

Aminullah. "Proses Pembelajaran Selama Masa Pandami Covid 19 (Studi KasusPelaksanaan PLP

Dasar.” Muspul Journal of Community Empowerment 3, no. 1 (2021).

Hanafi, Halid, La Adu, and Zainuddin. Ilmu Pendidikan Islam (1 Ed.). Deepublish, 2018. 
Hasan, S Hamid. "Pendidikan Sejarah Untuk Memperkuat Pendidikan Karakter." Paramita: Historical Studies Journal 22, no. 1 (2012).

Hermansyah, Mujiono, Luh Komang Sri Budiastuti, and Warohman. Modul Pengembangan Diri Melalui Layanan Bimbingan Dan Konseling SMK. Yogyakarta: Paramitha Publishing, 2009.

Kirom, A. "Peran Guru Dan Peserta Didik Dalam Proses Pembelajaran Berbasis Multikultural." Al-MuKirom, Arabbi: Jurnal Pendidikan Agama Islam 3, no. 1 (2017).

Mahmudah, Nurul, and Supiah. "Pemberdayaan Pada Anak-Anak Gang Dolly Di SMA Artaktika Surabaya Dengan Metode Asset Based Community Development.” Madani 1, no. 1 (2018).

Mawardi, Imam. "Pendampingan Belajar Di Rumah Berbasis Karakter Dengan Nilai-Nilai Religius Pada Masa Pandemik Covid-19.” Jurnal Terapan Abdimas 6, no. 2 (2021).

Nafrin, Irinna Aulia, and Hudaidah. "Perkembangan Pendidikan Indonesia Di Masa Panemi Covid-19." Edukatif: Jurnal Ilmu Pendidikan 3, no. 2 (2021).

Nella Agustin. Peran Guru Membentuk Karakter Siswa (Antologi Esai Mahasiswa Pendidikan Guru Sekolah Dasar). UAD Press, 2021.

Neoloka, A. N., and G. A. A. Landasan Pendidikan (1 Ed.). Kencana, 2017.

Ridwan, Abdullah S., and M. Kadri. Pendidikan Karakter: Pengembangan Karakter Anak Yang Islami (Cet-1). Bumi Aksara, 2016.

Saputri, Oktaviani Dwi, and Rahmawati. "Peran Guru Dalam Memberikan Pelajaran Tambahan (LES) Bagi Peserta Dididk Di Luar Jam Pelajaran Sekolah Sebagai Wujud Implementasi Pengapdian Kepada Masyarakat." In Seminar Nasional Pendidikan Program Pascasarjana Universitas PGRI Palembang, 2019.

Siagian, Nancy Florida. Guru Dan Perubahan: Peran Guru Di Dunia Pendidikan Dan Pembenagunan Sumber Daya Manusia. Global Aksara Pres, n.d.

Siti Maemunawati dan Muhammad Arif. Peran Guru, Orang Tua, Metode, Dan Media Pembelajaran: Starategi KBM Di Masa Pandemi Covid-19. Penerbit 3M Media Karya Serang, 2020.

Sofianti, Nurul Amelia. "Peran Bimbingan Belajar Pendidikan Agama Islam Dalam Pembentukan Karakter Peserta Didik Kelas II Di SDIT Assalam Pasirandu Curug Tangerang." JM2PI: Jurnal Mediakarya Mahasiswa Pendidi-Kan Islam 1, no. 1 (2020).

Surur, Agus Miftakus. "Standart Kinerja Pengajaran Dosen Pendidikan Matematik." Factor M 2, no. 1 (2019).

Wibowo, Imam Suwardi, and Ririn Farnisa. "Hubungan Peran Guru Dalam Proses Pembelajaran 


\section{Peran Guru Bimbel Dalam Pendidikan Karakter Anak}

Terhadap Prestasi Belajar Siswa.” Jurnal Genatala Pendidikan Dasar 3, no. 2 (2018).

Yusuf, M. Metode Penelitian: Kualitatif, Kuantitatif Dan Penelitian. Kencana, 2017.

Zein, Muh. "Peran Guru Dalam Pengembangan Pelajaran.” Jurnal Inspirasi Pendidikan 5, no. 2 (2016).

Zen, S., and Z. Dasar-Dasar Ilmu Pendidikan (1 Ed.). Kencana, 2017.

310 | FENOMENA, Vol. 20 No. 2 (Juli - Desember 2021) 